\title{
Problem of East Timorese Stolen Children in Indonesia:A Human Security Perspective
}

\author{
Munjin Syafik Asyari ${ }^{1}$, Aswin Baharuddin ${ }^{2}$, Adelita Lubis ${ }^{3}$, Nandito Oktaviano Guntur ${ }^{4}$, \\ Muhammad Setyawan Wirapraja ${ }^{5}$ \\ \{munjin.asyari@gmail.com¹, sawingbahar@gmail.com², adelita.lubis@gmail.com³, \\ ditoguntur10@gmail.com ${ }^{4}$,wirapraja78@gmail.com ${ }^{5}$ \}
}

Department of International Relation, Faculty of Social and Political Sciences, Universitas Hasanuddin, Jl. Perintis Kemerdekaan KM 10, Makassar, Indonesia ${ }^{1,2,4,5}$, Department of International Relation, Universitas Fajar, Jl. Prof. Abdurahman Basalamah No.101, Makassar, Indonesia $^{3}$

\begin{abstract}
This study aims to analyse the problems faced by East Timorese stolen children in Indonesia using the Human Security approach. Qualitative research includes research and collection of various empirical materials such as case studies, personal experiences, introspective, life stories, interviews, observational, historical, interactional, and visual texts. In conducting this data collection, researchers will use several methods, namely in-depth interviews, and documentation. This study found that these Stolen children were victims of conflict who had to face two phases of the violence. The first phase was when the Indonesian military forcibly transferred them from East Timor. While the second phase is when stolen children try to survive in Indonesia.
\end{abstract}

Keywords: Stolen Children, East Timor, Indonesia, Human Security

\section{Introduction}

Global political conditions during the Cold War also influenced the geopolitical architecture of Southeast Asia, including Indonesia. One of the impacts is the Indonesian intervention which aims to make East Timor part of the Republic of Indonesia. After joining the Republic of Indonesia for an extended period, the change occurred again after the wave of reform and democratisation in Indonesia after the New Order. During this phase, through a referendum, East Timor chose to separate from the Republic of Indonesia. The incident left conflict not only for each country but also citizens, including East Timorese children who were forced to separate from their families. These children are known as stolen children.

Historically this problem can be explored in the 1940s to 1960s in the context of the decolonisation process in the Southeast Asian region. East Timor was still under Portuguese colonisation, only to be able to gain independence in 1975. The Portuguese tried to do decolonisation by giving rights to the colonies to self-determination, including East Timor. In its implementation, the Portuguese requested Indonesian assistance. At that time, three choices were submitted to the people of East Timor in determining independence. First, it became independent and became a Portuguese state. Second, independence and become part of Indonesia. Third, independence and become a country free from the influence of Indonesia and the Portuguese.

These options make the internal political situation in East Timor heats up and out of control. There are three major parties (Fretilin, UDT, and Apodeti) that disagree with each other. These 
three parties have different preferences in determining East Timor's independence. Fretilin wanted to be completely free, UDT wanted to join the Portuguese, and Apodeti wanted to join Indonesia. In the process later, it should be noted that there had been a fraud committed by Apodeti in determining the vote (11 August 1975). This inevitably triggered a coup d'état carried out by Fretilin. The coup d'état carried out by Fretilin also succeeded in establishing Fretilin as the ruler.

The Fretilin party was opposed by the Indonesian government and the parties that opposed it. Because of his fear of communist spread, on 7 December 1975, the Indonesian military carried out an invasion called the Operation Code of Seroja (a full-scale invasion of East Timor). In operation, Fretilin was removed, and East Timor was united with Indonesia. This event became known as East Timor's integration with Indonesia. This process later became the root of the formation of community groups who sought to push East Timor to become an independent country.

Furthermore, this military takeover process left various problems for East Timor and Indonesia. A Commission for Reception, Truth and Reconciliation (CAVR) was formed by the United Nations. The CAVR said about 4,534 children had been forcibly transferred to Indonesia during the 1976-1999 period. This practice is carried out using a variety of transfer patterns carried out by both military personnel, government officials, charitable institutions, to religious institutions. They were moved and distributed throughout Indonesia, and South Sulawesi was one of them [1].

\section{Research Method}

This research is qualitative. Qualitative research includes research and collection of various empirical materials such as case studies, personal experiences, introspective, life stories, interviews, observational, historical, interactional, and visual texts [2]. Besides, this method is useful for gaining an understanding about the reasons, opinions and motivations that underlie a behaviour [3]. This type of research aims to comprehensively and comprehensively detail various matters relating to the lives of East Timorese stolen children in Makassar.

In conducting this data collection, researchers will use several methods, namely in-depth interviews, and documentation. The data in this study can be classified into primary data and secondary data. Primary data is data obtained from the first data source or first hand in the field. Meanwhile, secondary data is used as supporting data. Secondary data is the second data source after primary data. The secondary data in this study were obtained from documents, books, journals, and studies that have been carried out whose themes are in line with the problems of stolen children and East Timor.

The informants in this study were determined using a purposive technique that is the determination of informants carried out deliberately by setting specific criteria on the informants. These criteria are people who were abducted from East Timor before or after their integration with Indonesia. Furthermore, NGO activists such as Kontras and AJAR will also be informants on the issue of rehabilitation of the rights of stolen children. 


\section{Result and Discussion}

Some related studies have previously been stated by Klinken [4] who is entitled "The Children of Teams in Indonesia". This study reviews the history of East Timorese stolen children in Indonesia. This book aims to tell history from another perspective, namely the viewpoint of victims. The specific topics discussed in this book are generally related to the history of the transfer of stolen children and to question the story of how these stolen children were transferred. Another reference is far, another literacy that discusses the same theme is a journal written by Banks [5] with the title Protecting the Rights of the Child: Regulating Restorative Justice and Indigenous Practices in Southern Sudan and East Timor. In the article explained about the problem of children's rights in two problematic areas, namely Sudan and East Timor. The matter which then becomes the final target relates to the regulation of the rehabilitation of East Timor's children's rights and how the protection of children's rights is carried out.

This study then intends to continue the above research by giving an overview of the current situation of stolen children in Indonesia, especially South Sulawesi using the Human Security approach. In a relatively long period of time, issues of International Relations focus on the dynamics of relations between States relating to sovereignty and the use of the military as an instrument. In the 1990s, the focus of the security discourse above was tried to be updated and expanded by responding to the current global situation. Along with the reduction of territorial threats to the sovereignty of the State and on the other hand it raises issues such as poverty, health, human trafficking, as well as food, energy and environmental crises making various parties feel important to expand security studies.

According to thinkers such as Barry Buzan, Ole Waever and Jaap de Wilde [6], the broadening of the issue means that the study of International Security will no longer only focus on "State Security" but also be alert to the issue of "Human Security". It is within this framework that the terminology of traditional security issues occurs that focuses on State security and nontraditional security issues which emphasise its analysis of human security. The above idea was also confirmed by UNDP, which accurately described "human security" in 7 dimensions. The seven dimensions described in the 1994 Human Development Report include Economic Security, Food Safety, Health Safety, Environmental Security, Individual Security, Community Security, and Political Security [6].

Although there are various definitions put forward by several experts in the literature on human security, they all have similarities in the conception of security which is more oriented to the protection of individuals/humans than to the State. In this case, there is a common perception that the greatest threat to mankind is not only sourced from military attacks, but social, economic, and environmental problems will worsen human living conditions. Another significant development is that security issues are no longer dominated by the discipline of Security Studies. However, Human Security is a multi-disciplinary approach that views security issues as a study issue involving many disciplines such as International Relations, Development Studies, Strategic Studies, Public Administration and various other disciplines. This multidisciplinary approach is caused by the complexity of the problems studied, and human security becomes an intersection that connects social, economic, humanitarian, human rights, and the environment to create security and reduce human suffering [7].

This study focuses on analysing the phenomenon of stolen children using a human security approach. Analysis through this approach is expected to be able to complement previous studies looking at the problem of relations between East Timor and Indonesia from the perspective of 
military-based sovereignty and security. During the Indonesian occupation of East Timor, the transfer of children occurred from the first year (1975) until the period after the referendum (1999). In his report, it was written clearly that it was impossible to record the number of children transferred accurately. However, according to ICRC estimates, around 4,000 children have been transferred to Indonesia in various ways.

Further discussion about the transfer of these children then in its continuation, often discusses the matter of variations in the transfer of these children to Indonesia. Periodically, too, this variation of displacement forms specific patterns. The formation of this pattern must then be interpreted in terms of which transfer variants most often occur within particular decades. The periodisation can be divided into four, namely the First Period 1976-1979, the Second Period 1980-1989, the Third Period 1990-1998, and the Fourth Period is 1999 [1].

The First Period 1976-1979, in this period in its records, is the period in which the transfer of children occurred with massive. This is undoubtedly based on the fact that the initial period of Indonesian occupation in East Timor was a period of massive disruption and invasion. Many children lose their parents. Seeing this, middle-ranking officers, the government, and charitable institutions also accommodate these children. The background of taking from each party as well as this institution also seems to vary. However, in general, concerning all these parties, sometime after being transferred, these East Timorese children continued to receive unfair treatment. On the part of the government itself, political interests aimed at imaging can be said to be the main reason. Besides, concerning the middle officers mentioned earlier, it should be noted that the soldiers were also included there. The question arose as to whether the transfer by the army was a systematic order carried out by the army as an institution, but then in its notes and also the testimony of several victims and eyewitnesses, this could be done with a lot of mockeries (administrative letters) and not allowed to do illegally [1].

In many cases, what happened was illegal transfers by the army. Because of this (illegal), it is not surprising that coercion in the form of threats and violence often occurs. As for the charitable institutions that have been mentioned earlier, it is generally funded by Suharto's foundations. In this connection, like the government, these charitable institutions also tend to be political because they become an extension of the government itself to form a positive image - which intends to cover up the crimes and atrocities that occurred in the territory of East Timor.

The second period 1980-1989, In this period, the transfer carried out by the army itself continues. An important note that needs to be underlined here is that even high-ranking soldiers also transfer children. No different from the government, the removal of children carried out by high-ranking soldiers had the aim of building a positive image of Indonesia that 'cared for East Timorese children'. Apart from this, during this period, movements of religious institutions were recorded. In this case, based on the CAVR document notes, the religious institutions in question are Islamic religious institutions. To cite a few examples, the religious institutions in question are the Da'wah Islamic Council, the Nasrullah (Yakin) Islamic Welfare Foundation, and Lemoorai. These religious institutions then transferred these East Timorese children to Indonesia and were placed in boarding schools [1].

Third Period 1990-1998, In this period, the role of religious institutions increased. People who had previously graduated returned to East Timor and invited other children to follow in their footsteps. By offering education, these religious institutions continue to advance. Besides, in this period there were also new patterns which could be said to be coercive. The Ministry of Manpower issued a policy to improve education and employment for the people of Indonesia in general, including East Timor. Based on reports, many young people are forced to follow this. Again the military plays an essential role in doing this. Also noted when they got there, job training they got, and job guarantees were not given properly[1]. 
The fourth period is 1999. In the context of this year, the variant of the transfer of children is carried out by almost all the parties mentioned earlier. That is, both the government, charitable institutions, religious institutions, or even the military took part. A fundamental difference that can be noted is the question of the context of displacement. The 1999 period narrows in context after the referendum. Most transfers of children here occur based on evacuation. For this reason, the reason for each institution or party to move the children is this. However, as with previous transfers, the returns to these children were few [1].

In Makassar, ten stolen children have been identified. All of them do not have permanent jobs, some work as security, masons, boarding guards, so they have to move because of economic factors [8]. Within the scope of the South Sulawesi area, there are about 51 stolen children who were documented by Kontras and Asia Justice and Rights [9]. The initial findings of this study are that these stolen children experience 2 phases of violence. The first phase was when they were forcibly transferred by the Indonesian military from East Timor. While the second phase is when stolen children try to survive in Indonesia.

In the first phase, at the age of 6-11, they must be forced to separate from their families in East Timor. In a heated conflict situation in East Timor, the stolen children initially became Indonesian Military Operational Assistance Staff. The term transfer or mobilisation can be defined by force, and it is used because, at that time, the age of these children has not made it possible to make conscious choices. After the conflict subsided, they were then brought or moved to Indonesia. This forced transfer made them lose their essential identities such as family, religion and culture. This then had an impact on the survivors because they became very closed. In the view of the activist NGO AJAR who advocated for them, one of the obstacles in finding and identifying these stolen children was that they rarely socialised.

In the second phase, they face problems in efforts to earn a living. They are a very vulnerable group because they do not have access to fundamental rights, such as access to education and health insurance. This happens because they do not have legal identities such as Family Cards and Population Cards. Furthermore, when they want to return to East Timor, they are constrained by passport problems because they do not have a legal identity. Therefore, most importantly, how they must be fulfilled their fundamental rights first - starting from the legal identity, which later spread to health, education, and so forth. Then the right to recovery is carried out by the State, and the process is lengthy. Then, the right to obtain guarantees so that this event does not recur. So that the same treatment does not occur again in the future.

\section{Conclusion}

This study found that the conflicts that occurred in East Timor during the Integration and Disintegration phase with Indonesia left a problem that has not been resolved to date, namely the issue of stolen children. These stolen children are victims of conflicts that face two phases of violence. The first phase was when the Indonesian military forcibly transferred them from East Timor. While the second phase is when stolen children try to survive in Indonesia.

\section{Acknowledgements}

We would like to thank the LPPM Hasanuddin University for funding this research. 


\section{References}

[1] Commission for Reception, Truth, and Reconciliation Timor-Leste (CAVR).: Chega The Report of the Commission for Reception, Truth, and Reconciliation Timor-Leste.," Commission for Reception, Truth, and Reconciliation Timor-Leste (CAVR) (2005)

[2] N. K. Denzin and Y. S. Lincoln.: The SAGE Handbook of Qualitative Research Third Edition, California: Sage Publication (2005)

[3] U. S. Bakri.: Metode Penelitian Hubungan Internasionalm (Yogyakarta: Pustaka Pelajar) (2015)

[4] H. V. Klinken.: Anak-anak Tim-Tim di Indonesia (Jakarta: KPG) (2014)

[5] C. Banks.: Protecting the Rights of the Child: Regulating Restorative Justice and Indigenous Practices in Southern Sudan and and East Timor. The International Journal of Children's Rights, Vol. 19.pp. 167-193 (2011)

[6] Y. P. Hermawan.: Transformasi dalam Studi Hubungan Internasional Aktor, Isu dan Metodologi (Jakarta: Graha Ilmu) (2007)

[7] Agussalim Burhanuddin.: Studi Keamanan dan Isu-Isu Strategis (Makassar: Universitas Hasanuddin) (2017)

[8] Kontras Sulawesi.: Meniti Jalan Pulang: Membawa Anak-anak Timor Leste yang Dicuri dan Dibawa ke Indonesia untuk Bertemu Kembali dengan Keluarga Mereka. Asia Justice and Rights (2016)

[9] Kontras Sulawesi.: Nahebiti: Menyelami Kisah, Menanam Harapan Asia Justice and Rights Jakarta (2017) 